\title{
The Influence of Financial Performance on People's Business Credit in Banking Companies for the Period 2010-2019
}

\author{
Wiwi Ramadayanti ${ }^{1}$, Kosasih ${ }^{2}$ \\ 1.2Universitas Singaperbangsa Karawang \\ e-mail: wiwiramadayanti5@gmail.com, kosasih@staff.unsika.ac.id
}

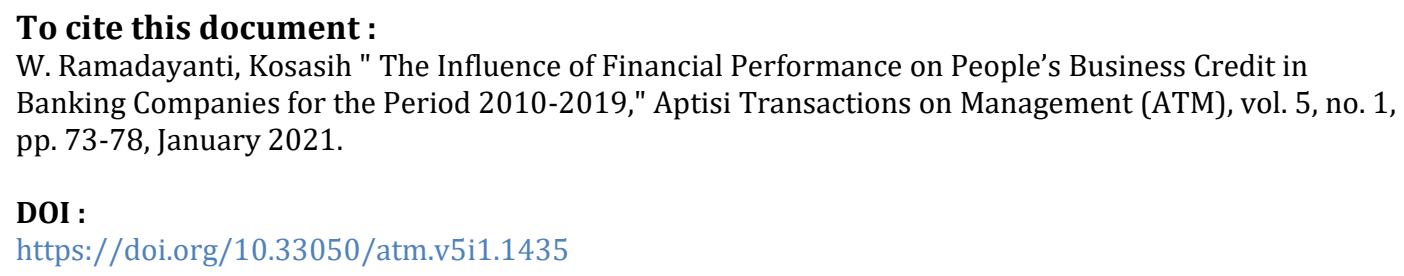

W. Ramadayanti, Kosasih " The Influence of Financial Performance on People's Business Credit in Banking Companies for the Period 2010-2019," Aptisi Transactions on Management (ATM), vol. 5, no. 1, pp. 73-78, January 2021.

DOI :

https://doi.org/10.33050/atm.v5i1.1435

\section{Abstract}

Bank Rakyat Indonesia, Bank Mandiri, and Bank Negara Indonesia are some of the banking companies that provide small business loans for MSME players with a view to find out the Capital Adequacy Ratio, Non Performing Loan and Return On Asset in banking companies that distribute people's Business Loans for the period 2010 - 2019. Researchers used Quantitative research methods with Descriptive and Verification research methods. People's Business Credit is one of the programs issued by the government to help small communities who have problems with capital. The KUR program is the solution, with a fairly fast, easy process and verry little interest. Research result on variables Capital Adequacy Ratio, Non-Performing Loan, and Return On Asset in Banking Companies for the period 2010 - 2019. The results of the study on the Capital Adequacy Ratio variable did not effect on the level of trust and Non Performing Loan variable there was a negative and significant level on the Business Credit to Banking Companies for the period 2010-2019.

Keywords: Capital Adequacy Ratio, Non Performing Loan, Return On Asset, People's Business Credit

\section{Introduction}

The distribution of KUR Bank Rakyat Indonesa from 2010 to 2019 continues to experience fluctuations due to internal and external factors. Lending helps people to carry out activities such as investment, consumption and distribution [1]. All of these activities are related to the use of money which is also an activity of community economic development [2]. The factor that influences the distribution of KUR is the Capital Adequacy Ratio (CAR), because used to show the ability to provide funds to accommodate the technical failures and personal problems [3]. The higher the risk, the higher the risk margin, this will reduce the level of income so that it affects the amount of credit extended. What affects the distribution of KUR is the Non-Performing Loan (NPL), which is the ratio of non-performing loans which can be determined by comparing the total non-performing loans with tollal loans [4]. The high NPL value in a company the greater the risk that a company bears, so that credit distribution will decrease because it is influenced by the soundness of a bank. Profitability or the bank's ability to seek profit effectively and efficiently. In addition, profitability is also used to see the health of a bank. A bank that has high advantage, it can said that the bank has a good performance [5]. With this, the public will not hesitate to save funds and invest and put full trust in the bank, so that later it can help smooth the activities carried out by the bank. Benefits can be seen in the results obtained. Although there are various indicators of profitability assessment that are often used by banks, researchers use the ROA ratio, because ROA takes into account the management's ability to obtain profitability and overall managerial efficiency. 
This research was conducted on three banking companies that distributed People's Business Credit. These banking companies are Bank Rakyat Indonesia, Bank Mandiri, and Bank Negara Indonesia.

\section{Research Method}

2.1. Capital Adequacy Ratio (CAR)

Reseach conducted by Darmawi states that one of the components of the capital factor is capital adequacy [6]. The ratio to test the bank's capital adequacy is the CAR (Capital Adequacy Ratio).

\subsubsection{Weighted Assets According to Ratio}

Reseach conducted by Sudirman RWA (Risk Weighted Assets) is the amount of risk scales for balance sheet assets and bank administrative accounts [7]. Balance sheet assets and administrative assets are weighted according to a predetermined level of risk weight. Each item in an asset is assigned a risk weight based on the level of risk inherent in the asset itself or class of customers or the nature of the collateral. Supervision regarding the provisions concerning RWA is to ensure that the maximum limit of RWA is based on the weighting determined by Bank Indonesia.

Total RWA = RWA for balance sheet assets + RWA for administrative assets.

\subsubsection{Calculation of Capital Adequacy Ratio (CAR)}

Reseach conducted by Sudirman how to calculate the amount of bank capital is by adding core capital plus supplementary capital [8]. Meanwhile, supplementary capital can only be calculated at a maximum of $100 \%$ of the core capital, which consists of fixed asset revaluation reserves, allowance for earning assets losses (PPAP), loan capital, and so on. The minimum capital requirement is calculated by multiplying the RWA by $8 \%$. The capital ratio is calculated by comparing the minimum capital with RWA.

Hasibuan the CAR ratio can be formulated as follows:

$\mathrm{CAR}=\frac{\text { Investasi } \mathrm{X} 100 \%}{\mathrm{ATMR}}$

\subsection{Non Performing Loan (NPL)}

The definition of Non Performing Loan (NPL) Reseach conducted by Kasmir is: "Nonperforming credit or bad credit is credit in which there are obstacles caused by 2 elements, namely from the bank in analyzing and from the customer who deliberately or unintentionally does not make payments in his obligation" [9].

Reseach conducted by Herman Darmawi the definition of Non Performing Loan (NPL) is as follows:

"So that we know the health of a bank by looking at the amount of problematic credit risk, It usually occurs when customers are slow in making principal and interest loan installment wich can result in lowering the performance of a bank".

So we can underline, Non Performing Loans are a ratio to measure the performance of a bank that has difficulty making payments so that it approaches problem loans.

\subsubsection{Calculation of Non Performing Loan (NPL)}

Non Performing Loans (NPL) is a ratio that shows the ratio of non-performing loans to total loans. The calculation of the ratio of Non Performing Loans (NPL) Mandala Manurung and Prathama Rahardja is as follows:

$$
\mathrm{NPL}=\frac{\text { Problem } \text { Credit } \times 100 \%}{\text { Total Credit }}
$$

Problem credit are payment that are experiencing delays. While total credit is a loan agreement with a debtor who requires that he be able to pay off his debt at a specified time Mandala Manurung and Prathama Rahardja [10]. 


\subsection{Return on Asset (ROA)}

Reseach conducted by Frianto Pandia Return on Assets is a ratio to see the profits obtained by a company in generating a profit [11]. In this case the profit generated is profit before interest and tax or EBIT.

\subsubsection{Factors Affecting Return On Assets (ROA)}

Reseach conducted by Malayu Hasibuan there are several inhibiting factors:

1. The resulting operating interest increases.

2. The proceeds from the share premium.

The factors that affect the decline in ROA are as follows:

1. High non-performing loans.

2. Increased bank operational expenses.

3. Increased reserves for credit write-offs.

4. Decreased interest income on the asset side.

The calculation of Return On Asset (ROA) Frianto Pandia can be calculated by:

$$
\text { Return On Asset }=\frac{\text { Provit Before Income } \times 100 \%}{\text { Total Income }}
$$

\section{Results and Analysis}

\subsection{Population and Sample}

Reseach conducted by Sugiyono the population is an object / subject that has characteristics and is then determined to be the core of the research. While the sample is number of characteristics used as the object of research [12].

\subsection{Data collection technique}

Data collection techniques are the first steps used to find the data we need Sugiyono [13]. There are several techniques or methods in data collection, namely literature study, documentation, internet research.

\subsection{Data analysis method}

\subsubsection{Normality Test}

To find out the data in a distribution we can use the normality test Sujarweni [14]. The way to determine normality is to look at the normal probability plot that compares the cumulative distribution and the normal distribution.

This normality test can also be done by looking at the normal distribution chart and by performing the Kolmogrov Smirnov test with the following criteria:

1. Significant number (sig) $>0.05$, then the data is well distributed

2. Significant number $(\mathrm{sig})<0.05$, then the data is not well distributed

\subsubsection{Multicollinearity Test}

Reseach conducted by Sujarweni states multicollinearity test is needed to see the similarity between variable in one model [15].

\subsubsection{Autocorrelation Test}

The autocorrelation test is to test whether in the model there is a correlation between the confounding and the confounding error in period t-1 (before). Reseach conducted by Sujarweni states testing with the autocorrelation test aims to determine the correlation between each variable in a certain period with the previous variable [16].

\subsubsection{Heteroscedasticity Test}

Reseach conducted by Ghozali years 2016 states this variable is used to see in the regression model that there is a difference between one variable and another [17]. If you experience a difference, we can call it heteroscedasticity.

\subsubsection{Descriptive Statistical Analysis}

The Effect of Capital Adequacy Ratio, Non Performing Loans and Return On Assets on the Distr ibution of People's Business Credit to Banking Companies Period 2010 - 2019 (Wiwi Ramadaya 
Reseach conducted by Sujarweni years 2015 states that descriptive statistics aim to describe various data characteristics such as mean, median, mode, quartile, variant, standard deviation. In this study, a descriptive analysis includes the number, sample, value, minimum, average value (mean) and standard deviation based on the variables being studied, namely CAR, NPL, and ROA on Community Business Credit Distribution using the SPSS application [18].

\subsubsection{Data Analysis Techniques}

Reseach conducted by Sugiyono activities carried out in data analysis, namely bringing together the same data and presenting the data in accordance with the variables being research and can answers the problem formulation section [19].

\subsubsection{Multiple Linear Regression Analysis}

Multiple linier regression analysis is used to see how the stated of a variable is when manipulated [20].

Where the formulation is:

$$
Y=\alpha+\beta_{1} X_{1}+\beta_{2} X_{2}+\beta_{3} X_{3}+\varepsilon
$$

Information :

$Y=$ Distribution of People's Business Credit

$\mathrm{X} 1=\mathrm{CAR}$

$X 2=N P L$

$\mathrm{X} 3=\mathrm{ROA}$

$\alpha=$ Disturbance Element

$\varepsilon=$ Constant Value

$\beta 1 \beta 2 \beta 3=$ Coefficient value of each independent variable

\subsubsection{Analysis of the coefficient of determination}

The coefficient of determination (R2) is a tool to measure the ability of a variable to variation. The coefficient of determination is between zero or one. A small R2 value means the ability of the independent variables to explain the limited variation in the dependent variable.

\section{Conclusion}

The results of this study used CAR, NPL and Profitability methods at the Bank Rakyat Indonesia Banking Company, Bank Mandiri and Bank Negara Indonesia for the period 2010 2019. In this study SPSS.

\subsection{Descriptive Statistical Analysis}

Descriptive statistics CAR with a total $(\mathrm{N})$ of 30 , a minimum value of 13.36 , a maximum value of 22.96, a mean value of 18.3563 and a standard deviation of 2.78596. Descriptive statistics of NPL with a total $(\mathrm{N})$ of 30 , a minimum value of 1.55 , a maximum value of 4.28 , a mean value of 2.4160 and a standard deviation of 0.69203 . Descriptive statistics of ROA with a total $(\mathrm{N})$ of 30 , a minimum value of 1.95 , a maximum value of 5.15 , a mean value of 3.4487 and a standard deviation of 0.82042 .

\subsection{Verification Analysis}

\subsubsection{Multiple Linear Regression Analysis}

Multiple Linear Regression Analysis aims to determine whether there is an influence of two or more independent variables on the dependent variable. CAR, NPL and ROA to Community Business Credit Distribution of 39.7\%. While the remaining 60.3\% Return on Assets is influenced by other variables not examined in this study.

\subsection{Hypothesis test}

The t-test is used to test how far the influence of the independent variables used in this study individually in explaining the dependent variable partially the t-count and the significance value of each variable. By using a significance level of $5 \%$, the t table value of 2.051 is obtained.

1. The Effect of CAR on the Distribution of People's Business Credit to Banking Companies 
Based on the results of the t-test test shows that the $t$-count value obtained in the variable CAR (X1):

Sig $=0.243>0.05 \mathrm{Ha}$ rejected tcount $(-1,195)<2,051 \mathrm{HO}$ is rejected

This means that partially, the CAR has no significant effect on the Distribution of People's Business Credit to Banking Companies for the period 2010 - 2019.

2. Effect of NPL on the Distribution of People's Business Credit to Banking Companies

Based on the results of the t-test, it shows that the t-count value obtained in the NPL variable $(\mathrm{X} 2)$ :

Sig $=0.001<0.05 \mathrm{Ha}$ Accepted

tcount $(-3.576)<2,051$ H0 Rejected

This means that partially, NPL have a negative and significant effect on the Distribution of People's Business Credit to Banking Companies for the period 2010 - 2019. The F-test aims to determine whether the independent variables jointly affect the dependent variable. $5 \%$ significance level can produce a Ftable value of 3.34. From the values above, it can be seen that the value of $F$ count obtained by the variable CAR (X1) and NPL (X2).

$\mathrm{Sig}=0.001<0.05 \mathrm{HO}$ Accepted

Fcount (8.873)> Ftable (3.34) HO Accepted

It can be concluded that simultaneously, the CAR and NPL have a significant effect on the Distribution of People's Business Credit to Banking Companies for the period 2010 - 2019.

The financial performance of the people's business credit in banking companies for the 20102019 period experienced significant changes. Bank that are eligible to be chosen as a place to look for capital, which have the lowest level of risk, and stable profits when making credit loans, namely the BRI bank.

It is hoped that it can provide information for distributors and customers who receive people's business credit loans (kur) in order to find out which banking companies are stable enough to make credit loans.

For other researchers, they can use other research methods or they can add other variables and examine different phenomena so that the results are more diverse and use a longer time span than previous researchers.

\section{References}

[1] Buchory, Herry ahmad. 2014. Analysis of the Effect of Capital, Credit Risk and Profitability to Implementation Banking Intermediation Fuction (Studi on Regional Development Bank All Over Indonesia Year 2012). European Journal of Business and management, 6 (24), pp. 20-32.

[2] Cai, Mei., and Zhonglin Huang. 2014. Analysis of Non Performing Loan and Capital Adequacy Ratio Among Chinese banks in the post-reform period in China, Journal of Advanced Studies in Finance, 5 (10), pp. 133-144.

[3] Damayanti, M., \& Adam, L. (2015). Program Kredit Usaha Rakyat (KUR) sebagai alat pendorong pengembangan UMKM di Indonesia. Tim Nasional Percepatan Penanggulangan Kemiskinan (TNP2K) Working Paper.

[4] Dendawijaya, Lukman. 2015. Manajemen Perbankan. Penerbit Ghalia Indonesia.

[5] Dudin, Mihail N. 2017. The Study Of Bank Nagari Credit Template, Indonesia. Journal of Internet Banking and Commerce, 22 (7), pp. 1-30.

[6] Farida Yuwono. (2011). Pengaruh pertumbuhan kredit dan Non Performing Loan (NPL) terhadap pertumbuhan modal perusahaan perbankan di Indonesia. Jurnal Manajemen \& Bisnis, 11(2), 8796.

[7] Ghozali, Imam. 2013. Aplikasi Analisis Multivariate dengan Program IBM SPSS 2.2. Edisi 7. Semarang: Badan Penerbit Universitas Diponegoro.

[8] Gizaw, Million., Matewos Kebede., and Sujata Selvaraj. 2015. The Impact of Credit Risk on Profitability Performance of Commercial banks in Ethiopia.

[9] Ida Ayu Adiatmayani Peling. (2018). Pengaruh LDR, NPL, dan BOPO Terhadap Profitabilitas pada PT. BPD Bali Periode tahun 2009 - 2016. E-Jurnal Manajemen Unud, Vol. 7, No. 6, 2018: 2999-3026 (ISSN : 2302-8912)

The Effect of Capital Adequacy Ratio, Non Performing Loans and Return On Assets on the Distr ibution of People's Business Credit to Banking Companies Period 2010 - 2019 (Wiwi Ramadaya 
[10] Jeriko Boyke Hoajahan.2014. Efektivitas Program Kredit Usaha Rakyat (KUR) Dalam Menigkatkan Kesejahteraan Masyarakat Oleh Bank Rakyat Indonesia (BRI) Di Kelurahan Harjosari Kec Medan Amplas.

[11] Kasmir. 2010. Analisis Laporan Keuangan. Edisi ke 3. Jakarta: Rajawali Pers.

[12] Ketut Tanti Kustina, (2018). "MSMEs, Credit Distribution and Non Performing Loan (NPL) to Wards Banking Companies Profit in Indonesia". International Journal of Social Sciences and Humanities, 2018 February.

[13] Kolapo, T funso. 2012. Credit Risk and Commercial Banks' Performance in Nigeria: A Panel Model Approach. Australian Journal of Business and Management research, 2 (2), pp. 31-38.

[14] Kusnandar, E. 2012. Analisis Faktor-faktor yang mempengaruhi Pemberian Kredit UMKM oleh Perbankan di Indonesia. Tesis Pascasarjana Universitas Indonesia, Jakarta.

[15] Mawar Rohman. (2013). Pengaruh Capital Adequacy Ratio (CAR), Non Performing Loan (NPL),Net Interst Margin (NIM), dan Loan To Deposit Ratio (LDR) terhadap Kinerja Keuangan Perbankan yang Terdaftar di Bursa Efek Indonesia 2008 - 2011

[16] Ramdany, Riza Ayu. 2012. Analisis Pengaruh Capital Adequacy Ratio, Operational Efficiency, dan Loan to Deposit Ratio terhadap Return on Assets (Studi Komparatif pada Bank BUMN di Indonesia Periode 2008-2011). Skripsi Fakultas Ekonomi Universitas Hasanudin, Makassar.

[17] Sugiyono. 2019. Metode Penelitian Kuantitatif Kualitatif dan R\&D. Bandung: Alfabeta.

[18] Sutrisno . 2013 . Manajemen Keuangan Teori, Konsep dan Aplikasi . Yogyakarta: Ekonosia

[19] Syamsudin, L. 2011. Manajemen Keuangan Perusahaan. Jakarta : Rajawali Pers.

[20] Wijaya, David. 2017. Manajemen Keuangan Konsep Dan Penerapannya. Jakarta : Grasindo 